\title{
Effects of 2,4-D and atrazine on degraded Oklahoma grasslands
}

\author{
C.K. RICE AND J.F. STRITZKE
}

\begin{abstract}
Three field studies were conducted for 2 years on degraded grasslands to compare the effects of 2,4-D [(2,4-dichlorophenoxy) acetic acid] and atrazine [2-chloro-4-(ethylamino)-6-(isopropylamino)-s-triazine] on weedy forbs and grass production. Atrazine was applied at 1.12 and $2.24 \mathrm{~kg} / \mathrm{ha}$ in April and 2,4-D was applied at 0.56 and $1.12 \mathrm{~kg} / \mathrm{ha}$ in May. One-half of all main plots were retreated the second year to compare 1 and 2 years of herbicide treatments. Major weedy forbs were heath aster (Aster ericoides L.), western ragweed (Ambrosia psilostachya D.C.), and lanceleaf ragweed (A mbrosia bidentata Michx.). Both density and standing crop of these major forb species were significantly reduced by the first year herbicide treatments. Atrazine was more effective on western ragweed and 2,4-D was more effective on heath aster and lanceleaf ragweed. Respraying with herbicides the second year did reduce forb density in a couple of instances, but had little effect on forb and grass standing crop. Grass standing crop in both years was similar after treatment with atrazine and 2,4-D. Herbicides increased grass standing crop by about $73 \%$ $(1,070 \mathrm{~kg} / \mathrm{ha})$ the first year and by an average of about $68 \%(1,320$ $\mathrm{kg} / \mathrm{ha}$ ) the second year.
\end{abstract}

Key Words: Common broomweed, heath aster, lanceleaf ragweed, western ragweed, Aster ericoides, Ambrosia bidentata, Ambrosia psilostachya, Gutierrezia dracunculoides

Overgrazed pastures and rangelands in Oklahoma have excessive populations of undesirable forbs. Sims and Dwyer (1965) observed that on tallgrass prairie, unpalatable annual forb species increase first with overgrazing followed by an increase in unpalatable perennial forbs. Dwyer (1958) reported reduced grass yields on tallgrass prairie of 68 and $55 \%$ when heath aster (Aster ericoides L.) and western ragweed (Ambrosia psilostachya D.C.), respectively, were present.

Use of 2,4-D[2,4-dichlorophenoxy)acetic acid] on pasture and rangeland has been the major tool employed by ranchers to control problem forbs. Hyder (1971) found 2,4-D applications on mixed grass prairies improved range condition and increased usable forage. Powell et al. (1982) observed a decrease in forb production and corresponding increase in grass production as the rate of 2,4-D increased from 0.28 to $1.68 \mathrm{~kg} / \mathrm{ha}$.

Atrazine [2-chloro-4-(ethylamino)-6-(isopropylamino)-s-triazine] has shown promise as a means of improving range condition and increasing grass production by controlling undesirable weeds in forages. Kay (1971) observed a quadrupled production of wheatgrass [Agropyron intermedium (Host) Beauv.] when atrazine was used for controlling downy brome (Bromus tectorum L.). Waller and Schmidt (1983) observed that atrazine stimulated a rapid recovery of warm-season grass remnants on overgrazed native grasslands in eastern Nebraska which they attributed to the reduction of competition from cool-season grasses.

The labeling and use of atrazine for controlling cool-season

\footnotetext{
Authors are senior agriculturalist and professor, Department of Agronomy, Oklahoma State University, Stillwater 74078.

This article has been approved by the Oklahoma Agricultural Experiment Station as Journal Article No. 5349.

Manuscript accepted 1 December 1988.
}

grasses and annual forbs has prompted interest in comparisons of atrazine and 2,4-D for controlling various annual and perennial forbs. Houston (1977) demonstrated a definite difference in susceptibility to atrazine between annual and perennial forbs and reported all annuals tested were highly susceptible to $2.0 \mathrm{~kg} /$ ha of atrazine applied in late fall. However, only 2 of the 17 perennial species, evening primrose (Oenothera albicaulis Pursh) and bottlebrush squirreltail [Sitanion hystrix (Nutt) J.G. Smith], were highly susceptible. Baker et al. (1980) concluded that atrazine improved range condition of tallgrass prairie and palatability of herbage by reducing the amount of prairie three-awn (Aristida oligantha Michx.) and by controlling western ragweed. Petersen et al. (1983) indicated that for the southern Rolling Plains of Texas, both 2,4-D and atrazine had the ability of shifting the competitive advantage toward more desirable forage plants when applied on rangeland with high densities of common broomweed [ Gutierrezia dracunculoides (D.C.) Blake], vervain (Verbena bipinnatifida Nutt.), redseed plantain (Plantago rhodosperma Dene.), and heartleaf nettle (Urtica chamaedryoides Pursh.). McGinnies (1984) reported that atrazine was more effective than 2,4-D for controlling annual forbs. He attributed poor control with 2,4-D to moisture stress on forbs at the time of the 2,4-D application.

The objectives of this study were to compare forb control and subsequent grass release with 2,4-D and atrazine on degraded grasslands and to determine the effects of these herbicides when applied in 2 consecutive years.

\section{Materials and Methods}

\section{Location Descriptions and Treatment Information}

Three grassland sites were selected in the spring of 1984 that had very low annual grass densities and had high undesirable forb densities. Locations I and II were on the Agronomy Research Range $11 \mathrm{~km}$ west of Stillwater, Oklahoma. Location III was on the Pawhuska Research Station at Pawhuska, Oklahoma. The experimental design in 1984 for all 3 studies consisted of a randomized complete block, with 5 treatments and 4 replications. The 5 treatments included atrazine at 1.12 and $2.24 \mathrm{~kg}$ ai/ha, 2,4-D butoxyethyl ester at 0.56 and $1.12 \mathrm{~kg} \mathrm{ae} / \mathrm{ha}$, and an untreated check. The plot size was $9 \times 12 \mathrm{~m}$. The residual biomass from 1984 was removed with a flail mower in March of 1985 while plants were still dormant. Experimental plots were then split in half, lengthwise, and randomly assigned either no treatment or retreatment. Environmental conditions for the 3 locations at the time of herbicide applications in 1984 and 1985 are listed in Table 1.

Location I was an overgrazed tallgrass prairie on a GranolaLucien sandy clay soil (Loamy, mixed, thermic, shallow Typic Haplustoll; shallow prairie range site). The area had a dense population ( $35 \mathrm{stems} / \mathrm{m}^{2}$ ) of heath aster. Other species present at the site included common broomweed, western ragweed, southern carrot (Daucus pusillus Michx.), big bluestem (Andropogon gerardii Vitman), little bluestem (Schizachyrium scoparium Michx.), downy brome, windmillgrass (Chloris verticillata Nutt.), witchgrass (Panicum capillare L.), prairie three-awn, blue grama [Bouteloua gracilis (H.B.K.) Lag. ex Steud.], and sideoats grama [B. curtipendula 
Table 1. Environmental conditions for herbicide applications at locations I, II, and III.

\begin{tabular}{|c|c|c|c|c|c|c|}
\hline & \multicolumn{6}{|c|}{ Location } \\
\hline & \multicolumn{2}{|c|}{1} & \multicolumn{2}{|c|}{ II } & \multicolumn{2}{|c|}{ III } \\
\hline & 1984 & 1985 & 1984 & 1985 & 1984 & 1985 \\
\hline $\begin{array}{l}\text { Atrazine } \\
\text { Appl. date } \\
\text { Air temp. (C) } \\
\text { Humidity (\%); } \\
\text { Soil temp. (C) }\end{array}$ & $\begin{array}{c}4 / 17 \\
14 \\
56 \\
16\end{array}$ & $\begin{array}{c}3 / 14 \\
16 \\
68 \\
10\end{array}$ & $\begin{array}{c}4 / 17 \\
14 \\
56 \\
16\end{array}$ & $\begin{array}{c}3 / 14 \\
16 \\
68 \\
10\end{array}$ & $\begin{array}{c}4 / 11 \\
16 \\
49 \\
18\end{array}$ & $\begin{array}{c}3 / 15 \\
13 \\
68 \\
9\end{array}$ \\
\hline $\begin{array}{l}\text { 2,4-D } \\
\text { Appl. date } \\
\text { Air temp. (C) } \\
\text { Humidity (\%) } \\
\text { Soil temp. (C) }\end{array}$ & $\begin{array}{c}5 / 14 \\
22 \\
56 \\
21\end{array}$ & $\begin{array}{c}5 / 8 \\
24 \\
70 \\
20\end{array}$ & $\begin{array}{c}5 / 14 \\
22 \\
56 \\
21\end{array}$ & $\begin{array}{c}5 / 8 \\
24 \\
70 \\
20\end{array}$ & $\begin{array}{c}5 / 14 \\
23 \\
54 \\
20\end{array}$ & $\begin{array}{l}5 / 2 \\
24 \\
62 \\
21\end{array}$ \\
\hline
\end{tabular}

(Michx.) Torr.]. Treatments in 1984 were applied with a tractormounted spray boom delivering $187 \mathrm{l} /$ ha through 8,003 flat fan nozzle tips. Atrazine was applied on 17 April when heath aster was $3 \mathrm{~cm}$ in height. The 2,4-D applications were made on 14 May when heath aster was 15 to $25 \mathrm{~cm}$ in height. Herbicides were reapplied on $1 / 2$ of the main plot area in 1985 with a compressed air bicycle sprayer delivering $178 \mathrm{1} /$ ha through 11,003 flat fan nozzle tips. Atrazine application was made on $14 \mathrm{March}$ when heath aster was dormant. The 2,4-D was applied on 8 May when heath aster was 25 to $35 \mathrm{~cm}$ in height.

Location II was a degraded bermudagrass [Cynodon dactylon (L.) Pers.] pasture located on a Stephenville fine sandy loam soil
(Fine-loamy, siliceous, thermic Ultic Haplustalf). Western ragweed dominated the overstory $\left(65 \mathrm{stems} / \mathrm{m}^{2}\right)$, but other species were present including southwestern carrot, sericea lespedeza [Lespedeza cuneata (Dumont.) G Don], common lespedeza [Lespedeza striata (Thunb.) H.B.A.], little bluestem, and prairie dropseed (Sporobolus heterolepis Gray). Treatments in 1984 were applied with a tractor mounted spray boom delivering $187 \mathrm{l} /$ ha through 8,003 flat fan nozzle tips. Atrazine was applied on 17 April when western ragweed was in the 4-leaf stage and $8 \mathrm{~cm}$ in height, and 2,4-D was applied on 14 May when western ragweed was in the 8- to 10-leaf stage and $25 \mathrm{~cm}$ in height. Herbicides were reapplied in 1985 with a compressed air bicycle sprayer delivering $178 \mathrm{l} / \mathrm{ha}$ through 11,003 flat fan nozzle tips. Atrazine applications were made on 14 March when western ragweed was dormant. The 2,4-D was applied on 8 May when the western ragweed was in the 4- to 8-leaf stage and $15 \mathrm{~cm}$ in height.

Location III was a tallgrass prairie on a Parsons-Carytown, silty clay loam soil (Fine, mixed, thermic Mollic Albaqualf; claypan prairie range site). The area had a dense population (154 plants $/ \mathrm{m}^{2}$ ) lanceleaf ragweed (Ambrosia bidentata Michx.). The other species present included heath aster, southwestern carrot, big bluestem, little bluestem, switchgrass (Panicum virgatum L.), and indiangrass [Sorghastrum nutans (L.) Nash]. Treatments in 1984 were applied with a compressed air bicycle sprayer delivering $187 \mathrm{l} /$ ha through 11,003 flat fan nozzle tips. Atrazine was applied on 1.1 April when lanceleaf ragweed was from cotyledon to 4-leaf stage and was from 3 to $6 \mathrm{~cm}$ in height. The 2,4-D was applied on 14 May when lancelaf ragweed was in the 4- to 6-leaf stage and 8 to $10 \mathrm{~cm}$ in height. Herbicides were reapplied in 1985 with a compressed air bicycle sprayer delivering $178 \mathrm{l} /$ ha through 11,003 flat fan nozzle

Table 2. Forb dendity and forb and grass standing crop for locations, I, II, III in 1984.1

\begin{tabular}{|c|c|c|c|c|c|c|c|c|c|}
\hline \multirow{3}{*}{$\begin{array}{l}\text { Orthogonal comparison } \\
\text { Location I. }\end{array}$} & \multicolumn{4}{|c|}{ Density } & \multicolumn{5}{|c|}{ Standing crop } \\
\hline & & & $/ \mathrm{m}^{2}$ & & & & $-\mathrm{kg} / \mathrm{h}$ & & \\
\hline & & GUEDR & ASTER & OF & TOTG & GUEDR & ASTER & OF & \\
\hline $\begin{array}{l}\text { No herbicide } \\
\text { VS herbicide }\end{array}$ & & $\begin{array}{l}8^{* * * *} \\
0\end{array}$ & $\begin{array}{l}35 * * * * \\
7\end{array}$ & $\begin{array}{l}7 \\
5\end{array}$ & $\begin{array}{l}1420 \\
2220^{* * *}\end{array}$ & $\begin{array}{l}50 * * * \\
0\end{array}$ & $\begin{array}{l}360^{* * * *} \\
80\end{array}$ & $\begin{array}{r}110 \\
90\end{array}$ & \\
\hline $\begin{array}{l}\text { Atrazine } \\
\text { vS 2,4-D }\end{array}$ & & $\begin{array}{l}1 \\
0\end{array}$ & $\begin{array}{l}15 * * * \\
0\end{array}$ & $\begin{array}{l}5 \\
5\end{array}$ & $\begin{array}{l}2310 \\
2120\end{array}$ & $\begin{array}{l}10^{* * * *} \\
0\end{array}$ & $\begin{array}{c}170^{* * *} \\
0\end{array}$ & $\begin{array}{l}130^{* * *} \\
50\end{array}$ & \\
\hline $\begin{array}{l}\text { Atrazine, } 1.12 \mathrm{~kg} \\
\text { VS } 2.24 \mathrm{~kg}\end{array}$ & & $\begin{array}{l}2 \\
0\end{array}$ & 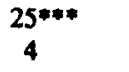 & $\begin{array}{l}5 \\
5\end{array}$ & $\begin{array}{l}2230 \\
2400\end{array}$ & $\begin{array}{r}10 \\
0\end{array}$ & $\begin{array}{l}310^{* * * *} \\
30\end{array}$ & $\begin{array}{l}140 \\
120\end{array}$ & \\
\hline $\begin{array}{l}2,4-D, 0.56 \mathrm{~kg} \\
\text { VS } 1.12 \mathrm{~kg}\end{array}$ & & $\begin{array}{l}\mathbf{0} \\
\mathbf{0}\end{array}$ & $\begin{array}{l}0 \\
0\end{array}$ & $\begin{array}{l}3 \\
6\end{array}$ & $\begin{array}{l}2190 \\
2050\end{array}$ & $\begin{array}{l}0 \\
0\end{array}$ & $\begin{array}{l}0 \\
0\end{array}$ & $\begin{array}{l}30 \\
80\end{array}$ & \\
\hline Location II. & & & AMBPC & OF & TOTG & AMBPC & OF & LESSP & \\
\hline $\begin{array}{l}\text { No herbicide } \\
\text { VS herbicide }\end{array}$ & & & $\begin{array}{l}64 * * * \\
10\end{array}$ & $\begin{array}{l}2^{*} \\
0\end{array}$ & $\begin{array}{l}1480 \\
2770^{* * *}\end{array}$ & $\begin{array}{l}410^{* * * *} \\
60\end{array}$ & $\begin{array}{l}10 \\
10\end{array}$ & $\begin{array}{l}230 \\
140\end{array}$ & \\
\hline $\begin{array}{l}\text { Atrazine } \\
\text { VS 2,4-D }\end{array}$ & & & $\frac{4}{16 * *}$ & $\begin{array}{l}0 \\
1\end{array}$ & $\begin{array}{l}2980^{*} \\
2560\end{array}$ & $\begin{array}{l}20 \\
90 * *\end{array}$ & $\begin{array}{r}0 \\
20\end{array}$ & $\begin{array}{c}10 \\
280^{* * * *}\end{array}$ & \\
\hline $\begin{array}{l}\text { Atrazine, } 1.12 \mathrm{~kg} \\
\text { VS } 2.24 \mathrm{~kg}\end{array}$ & & & $\begin{array}{l}5 \\
2\end{array}$ & $\begin{array}{l}0 \\
0\end{array}$ & $\begin{array}{l}3000 \\
2970\end{array}$ & $\begin{array}{l}30 \\
10\end{array}$ & $\begin{array}{l}0 \\
0\end{array}$ & $\begin{array}{r}10 \\
0\end{array}$ & \\
\hline $\begin{array}{l}2,4-D, 0.56 \mathrm{~kg} \\
\text { VS } 1.12 \mathrm{~kg}\end{array}$ & & . & $\begin{array}{c}27+4 *+ \\
5\end{array}$ & $\begin{array}{l}2 \\
0\end{array}$ & $\begin{array}{l}2600 \\
2520\end{array}$ & $\begin{array}{l}160^{* *} \\
30\end{array}$ & $\begin{array}{r}50 \\
0\end{array}$ & $\begin{array}{l}210 \\
340^{* *}\end{array}$ & \\
\hline Location III. & AMBBI & ASTER & AMBPC & OF & TOTG & AMBBI & ASTER & AMBPC & OF \\
\hline $\begin{array}{l}\text { No herbicide } \\
\text { VS herbicide }\end{array}$ & $\begin{array}{l}154^{* * * *} \\
19\end{array}$ & $\begin{array}{l}19 * * * * \\
6\end{array}$ & $\begin{array}{l}16^{* * *} \\
6\end{array}$ & $\begin{array}{l}18^{* * * *} \\
5\end{array}$ & $\begin{array}{l}1500 \\
2610^{* * * *}\end{array}$ & $\begin{array}{l}810^{* * * *} \\
110\end{array}$ & $\begin{array}{l}150^{* * * *} \\
40\end{array}$ & $\begin{array}{l}150 * * \\
70\end{array}$ & $\begin{array}{l}70^{* *} \\
30\end{array}$ \\
\hline $\begin{array}{l}\text { Atrazine } \\
\text { VS 2,4-D; }\end{array}$ & $\begin{array}{c}29 * * \\
9\end{array}$ & $\begin{array}{l}11 * * * * \\
0\end{array}$ & $11^{* * * *}$ & $\begin{array}{l}9 * * \\
1\end{array}$ & $\begin{array}{l}2450 \\
2770\end{array}$ & $\begin{array}{l}180^{* * * *} \\
40\end{array}$ & $\begin{array}{c}80 * * * \\
0\end{array}$ & $\begin{array}{c}130^{* * * *} \\
0\end{array}$ & $\begin{array}{l}50^{* * *} \\
10\end{array}$ \\
\hline $\begin{array}{l}\text { At razine, } 1.12 \mathrm{~kg} \\
\text { VS } 2.24 \mathrm{~kg}\end{array}$ & $\begin{array}{l}52 * * * * \\
5\end{array}$ & $\begin{array}{r}14 \\
8\end{array}$ & $\begin{array}{c}16^{* *} \\
6\end{array}$ & $\begin{array}{l}17 \\
10\end{array}$ & $\begin{array}{l}2080 \\
2810^{* *}\end{array}$ & $\begin{array}{l}330^{* * * * *} \\
30\end{array}$ & $\begin{array}{l}90 \\
70\end{array}$ & $\begin{array}{l}200 * * * \\
60\end{array}$ & $\begin{array}{l}40 \\
60\end{array}$ \\
\hline $\begin{array}{l}2,4-D, 0.56 \mathrm{~kg} \\
\text { VS } 1.12 \mathrm{~kg}\end{array}$ & $\begin{array}{r}0 \\
17\end{array}$ & $\begin{array}{l}0 \\
0\end{array}$ & $\begin{array}{l}0 \\
1\end{array}$ & $\begin{array}{l}1 \\
1\end{array}$ & $\begin{array}{l}2970 \\
2580\end{array}$ & $\begin{array}{r}0 \\
80\end{array}$ & $\begin{array}{l}\mathbf{0} \\
\mathbf{0}\end{array}$ & $\begin{array}{r}0 \\
10\end{array}$ & $\begin{array}{l}10 \\
10\end{array}$ \\
\hline
\end{tabular}

$*, * * * * * *$ Significant at the $0.10,0.05$, and 0.01 levels, respectively.

'GUEDR = common broomweed, ASTER = heath aster, OF $=$ other forbs, TOTG $=$ total grasses, $A M B P C=$ western ragweed, LESSP $=$ lespedeza sp, AMBBI $=$ lanceleaf ragweed. 
tips. Atrazine was applied on 15 March when lanceleaf ragweed was dormant. The 2,4-D was applied on 2 May when lanceleaf ragweed was in the 4- to 6-leaf stage and 8 to $15 \mathrm{~cm}$ in height.

\section{Density and Forage Sampling}

Forb density and forb and grass standing crop were measured in 1984 and 1985 at all 3 locations between 16 and 23 June. Forb density was measured for each weed species present in 6 randomly placed $0.16-\mathrm{m}^{2}$ quadrats in all plots. Forb and grass standing crop was determined in each of the six $0.16-\mathrm{m}^{2}$ quadrats by the modified weight-estimate method of double sampling (Pechanec and Pickford 1937) in which 1 of the 6 quadrats was randomly selected for clipping. Clipped herbage was hand separated and weighed in the field. The clipped samples were oven dried at $70^{\circ} \mathrm{C}$ for $72 \mathrm{~h}$ and reweighed. Field-estimated herbage green weights were subsequently corrected for estimator error by the ratio technique (Ahmed et al. 1983) and moisture content.

Forb densities and standing crops were analyzed separately for the 3 locations by analysis of variance. Selected means were compared with orthogonal contrasts to determine treatment response of forbs and grasses.

\section{Results and Discussion}

Rainfall was above average in both treatment years at all locations. Total rainfall at Locations I and II for March through June of 1984 and 1985 was $61 \mathrm{~mm}$ and $122 \mathrm{~mm}$, respectively, above the $86 \mathrm{~mm}$ average for this time period. Total rainfall at Location III for March through June 1984 and 1985 was $119 \mathrm{~mm}$ and $464 \mathrm{~mm}$, respectively, which was above the $89 \mathrm{~mm}$ average for this time period.

\section{4}

Both density and standing crop of common broomweed and heath aster were significantly reduced by both herbicides at Location I (Table 2). Herbicides reduced forb standing crop an average of $67 \%(350 \mathrm{~kg} /$ ha reduction), and increased grass standing crop $56 \%(800 \mathrm{~kg} / \mathrm{ha}$ increase). Comparisons of the 2 levels of 2,4-D treatment indicated no differences in control of either forb species present or the grass standing crop associated with the 2 rates. This indicated that the $0.56 \mathrm{~kg}$ rate of 2,4-D was sufficient to control the undesirable forbs present at this location. Atrazine was not as effective at reducing density of heath aster or standing crop of the forbs as 2,4-D. However, no difference in grass standing crop among the herbicide treatments was measured. Also, the 1.12 $\mathrm{kg} / \mathrm{ha}$ rate of atrazine was not as effective as the $2.24 \mathrm{~kg} / \mathrm{ha}$ rate for control of heath aster.

At Location II, density and standing crop of western ragweed were reduced by 68 and $85 \%$, respectively, by herbicide treatments and grass standing crop was increased $87 \%$ (Table 2). Atrazine treatments controlled western ragweed better than $2,4-D$, and this was attributed to the reduced control of western ragweed with the $0.56 \mathrm{~kg}$ ae/ha rate of 2,4-D. Total grass standing crop was not significantly different between rates of atrazine or 2,4-D; however, differences between forb standing crop (western ragweed and lespedeza) with rate of 2,4-D were significant.

Herbicide treatments in 1984 resulted in significant decreases in

Table 3. Forb density and forb and grass standing crop for Location I in 1985.1

\begin{tabular}{|c|c|c|c|c|c|c|c|}
\hline & \multicolumn{3}{|c|}{ Density } & \multicolumn{4}{|c|}{ Standing crop } \\
\hline & GUEDR & ASTER & OF & TOTG & GUEDR & ASTER & OF \\
\hline \multicolumn{8}{|c|}{$\begin{array}{l}\text { Treatment means (for } 1 \text { and } 2 \text { years treatment) } \\
\text { Treatment in } 1984\end{array}$} \\
\hline $\begin{array}{l}\text { No herbicide } \\
\text { Atrazine, } 1.12 \mathrm{~kg} \\
\text { Atrazine, } 2.24 \mathrm{~kg} \\
2,4-\mathrm{D}, 0.56 \mathrm{~kg} \\
2,4-\mathrm{D}, 1.12 \mathrm{~kg}\end{array}$ & $\begin{array}{l}5 \\
7 \\
9 \\
1 \\
1\end{array}$ & $\begin{array}{r}26 \\
19 \\
1 \\
1 \\
0\end{array}$ & $\begin{array}{r}12 \\
5 \\
4 \\
1 \\
1\end{array}$ & $\begin{array}{l}2100 \\
3190 \\
3070 \\
2650 \\
3180\end{array}$ & $\begin{array}{r}210 \\
90 \\
180 \\
20 \\
0\end{array}$ & $\begin{array}{r}390 \\
280 \\
10 \\
0 \\
0\end{array}$ & $\begin{array}{r}200 \\
70 \\
40 \\
170 \\
80\end{array}$ \\
\hline $\begin{array}{l}\text { Treated in } 1984 \text { and } \\
\text { No herbicide } \\
\text { Atrazine, } 1.12 \mathrm{~kg} \\
\text { Atrazine, } 2.24 \mathrm{~kg} \\
2,4-D, 0.56 \mathrm{~kg} \\
2,4-D, 1.12 \mathrm{~kg}\end{array}$ & $\begin{array}{l}1 \\
0 \\
0 \\
0 \\
0\end{array}$ & $\begin{array}{r}45 \\
14 \\
2 \\
0 \\
0\end{array}$ & $\begin{array}{r}14 \\
4 \\
1 \\
1 \\
1\end{array}$ & $\begin{array}{l}1970 \\
3340 \\
3410 \\
3210 \\
3410\end{array}$ & $\begin{array}{r}20 \\
60 \\
0 \\
0 \\
0\end{array}$ & $\begin{array}{r}550 \\
180 \\
20 \\
0 \\
0\end{array}$ & $\begin{array}{r}360 \\
80 \\
40 \\
40 \\
0\end{array}$ \\
\hline $\begin{array}{l}\text { Orthogonal main eff } \\
\text { No herbicide } \\
\text { X herbicide }\end{array}$ & $\begin{array}{l}\text { ooled over } \\
3 \\
2\end{array}$ & $\begin{array}{l}2 \text { years tre } \\
36^{* * *} \\
5\end{array}$ & $13 \pm$ & $\begin{array}{l}2030 \\
3180^{* * *}\end{array}$ & $\begin{array}{r}110 \\
40\end{array}$ & $\begin{array}{l}470^{* * * *} \\
60\end{array}$ & $\begin{array}{l}280^{*-* *} \\
60\end{array}$ \\
\hline $\begin{array}{l}\text { Atrazine } \\
\text { X 2,4-D }\end{array}$ & $\begin{array}{l}4 * * * \\
1\end{array}$ & $\begin{array}{l}9^{*} \\
0\end{array}$ & $\begin{array}{l}4 \\
5\end{array}$ & $\begin{array}{l}3250 \\
3110\end{array}$ & $\begin{array}{c}80^{*} \\
0\end{array}$ & $\begin{array}{c}120 * * \\
0\end{array}$ & $\begin{array}{l}60 \\
70\end{array}$ \\
\hline $\begin{array}{l}\text { Atrazine, } 1.12 \mathrm{~kg} \\
\times 2.24 \mathrm{~kg}\end{array}$ & $\begin{array}{l}4 \\
5\end{array}$ & $1_{1}^{* *}$ & $\begin{array}{l}5 \\
2\end{array}$ & $\begin{array}{l}3270 \\
3240\end{array}$ & $\begin{array}{l}80 \\
90\end{array}$ & $\begin{array}{l}230^{* * * *} \\
20\end{array}$ & $\begin{array}{l}80 \\
40\end{array}$ \\
\hline $\begin{array}{l}2,4-\mathrm{D}, 0.56 \mathrm{~kg} \\
\times 1.12 \mathrm{~kg}\end{array}$ & 1 & $\begin{array}{l}0 \\
0\end{array}$ & $\begin{array}{l}6^{*} \\
3\end{array}$ & $\begin{array}{l}2930 \\
3290\end{array}$ & $\begin{array}{r}10 \\
0\end{array}$ & $\begin{array}{l}0 \\
0\end{array}$ & $\begin{array}{r}100 \\
40\end{array}$ \\
\hline $\begin{array}{l}\text { Orthogonal interacti } \\
\text { No herbicide } \\
\mathrm{X} \text { herbicide }\end{array}$ & $\begin{array}{l}984 \times 1985 \\
\text { ns }\end{array}$ & tment) & $* *$ & ns & ns & $* * *$ & $* * *$ \\
\hline $\begin{array}{l}\text { Atrazine } \\
\times \text { 2,4-D }\end{array}$ & $* * *$ & ns & $* *$ & ns & ns & ns & $*$ \\
\hline $\begin{array}{l}\text { Atrazine, } 1.12 \mathrm{~kg} \\
\times 2.24 \mathrm{~kg}\end{array}$ & ns & ns & ns & ns & ns & ns & ns \\
\hline $\begin{array}{l}2,4-\mathrm{D}, 0.56 \mathrm{~kg} \\
\times 1.12 \mathrm{~kg}\end{array}$ & ns & ns & ns & ns & ns & ns & ns \\
\hline
\end{tabular}

$*, * * * * * *$ Significant at the $0.10,0.05$, and 0.01 levels, respectively.

'GUEDR = common broomweed, ASTER = heath aster, OF = other forbs, TOTG = total grasses. 
both plant density and standing crop of all forbs present at Location III (Table 2). Average forb standing crop was reduced $79 \%$ $(930 \mathrm{~kg} / \mathrm{ha})$, and grass standing crop increased $74 \%(1,110 \mathrm{~kg} / \mathrm{ha})$ on herbicide treated plots. Treatments with 2,4-D controlled all forbs better than atrazine. Although control of undesirable forbs was better with 2,4-D, average grass standing crop was not statistically different from that in atrazine plots. However, comparisons of forb control with the 2 rates of atrazine indicated that the higher rate gave better control of ragweeds and this resulted in a 35\% increase in grass standing crop. Evidently the higher rate of atrazine was necessary on this silty clay loam soil to adequately control the weed species present. Both rates of 2,4-D adequately controlled the undesirable forbs and no significant differences in grass standing crop were measured between the rates.

\section{5}

Retreatment for forb control was not necessary in 1985 at Location I since there was excellent grass production with both rates of 2,4-D and atrazine applied in 1984 (Table 3). Significant interactions associated with density and standing crop of heath aster and other forbs were measured when comparing no herbicide versus herbicide across retreatment. This was due to the large increase in the second year of the forb populations in the plots not treated with herbicides (data not presented). Significant interactions were also observed when comparing atrazine versus 2,4-D across retreatment because fewer broomweed plants grew in the 2,4-D plots that were not retreated than in the atrazine plots (data not presented). This may have been due to the better control of these weeds in 1984 with 2,4-D (Table 2); and, as a result, there might have been less seed production in the 2,4-D plots. A lack of complete control with atrazine in 1984 could have allowed reseeding of the plots and this contributed to a higher population of weedy forbs in 1985. These forb interactions were considered minor since there were no significant grass standing crop interactions associated with retreatments.

Retreatment in 1985 at Location II had little effect on forb density or forb and grass standing crop with the exception of standing crop of western ragweed in the 2,4-D treatments (Table 4). Standing crop of western ragweed in plots treated with the low rate of 2,4-D was significantly reduced with retreatment in 1985 . The comparison of the main effect between no herbicide versus herbicide treatment indicated an $82 \%$ decrease in the number of western ragweed stems with herbicide treatments. This corresponded to an $85 \%$ reduction in standing crop of western ragweeds $(450 \mathrm{~kg} /$ ha reduction). The herbicide treatments resulted in increased grass standing crop of $1,240 \mathrm{~kg} / \mathrm{ha}$ for the herbicide treated plots. Comparisons of atrazine versus 2,4-D indicated no significant differences in any of the variables measured. Thus, both herbicides reduced western ragweed populations and increased grass yields the second year. No differences were measured between the 2 rates of atrazine for standing crop of grass or undesirable forbs. However, standing crop of lespedeza was significantly increased with the low rate of 2,4-D. In 1984, we observed that the lespedeza production appeared to be from common lespedeza, but in 1985 , the lespedeza standing crop was from sericea lespedeza. This would indicate that sericea lespedeza might

Table 4. Forb density and forb and grass standing crop for Location 11 in 1985.1

\begin{tabular}{|c|c|c|c|c|c|c|}
\hline & \multicolumn{2}{|l|}{ Density } & \multicolumn{4}{|c|}{ Standing crop } \\
\hline & AMBPC & OF & TOTG & AMBPC & OF & $\mathbf{L S}$ \\
\hline \multicolumn{4}{|c|}{ Treatment means (for 1 and 2 years treatment) } & & & \\
\hline $\begin{array}{l}\text { Treated in } 1984 \\
\text { No herbicide } \\
\text { Atrazine, } 1.12 \mathrm{~kg} \\
\text { Atrazinc, } 2.24 \mathrm{~kg} \\
2,4-\mathrm{D}, 0.56 \mathrm{~kg} \\
2,4-\mathrm{D}, 1.12 \mathrm{~kg}\end{array}$ & $\begin{array}{r}44 \\
8 \\
5 \\
19 \\
9\end{array}$ & $\begin{array}{l}8 \\
2 \\
6 \\
6 \\
5\end{array}$ & $\begin{array}{l}1800 \\
3230 \\
2790 \\
2290 \\
2710\end{array}$ & $\begin{array}{r}620 \\
100 \\
70 \\
280 \\
90\end{array}$ & $\begin{array}{r}30 \\
50 \\
80 \\
210 \\
40\end{array}$ & $\begin{array}{r}110 \\
70 \\
30 \\
570 \\
50\end{array}$ \\
\hline $\begin{array}{l}\text { Treated in } 1984 \text { and } \\
\text { No herbicide } \\
\text { Atrazine, } 1.12 \mathrm{~kg} \\
\text { Atrazine, } 2.24 \mathrm{~kg} \\
2,4-D, 0.56 \mathrm{~kg} \\
2,4-D, 1.12 \mathrm{~kg}\end{array}$ & $\begin{array}{r}36 \\
4 \\
1 \\
5 \\
1\end{array}$ & $\begin{array}{l}4 \\
3 \\
2 \\
3 \\
1\end{array}$ & $\begin{array}{l}1760 \\
3590 \\
3190 \\
3000 \\
3410\end{array}$ & $\begin{array}{r}440 \\
30 \\
10 \\
50 \\
10\end{array}$ & $\begin{array}{l}40 \\
20 \\
30 \\
60 \\
20\end{array}$ & $\begin{array}{r}110 \\
0 \\
0 \\
700 \\
30\end{array}$ \\
\hline $\begin{array}{l}\text { Orthogonal main effe } \\
\text { No herbicide } \\
\mathrm{X} \text { herbicide }\end{array}$ & $\begin{array}{l}\text { ooled over } \\
40^{* * *} \\
7\end{array}$ & $\begin{array}{c}\text { ears } t \\
6 \\
3\end{array}$ & $\begin{array}{l}1780 \\
3020^{* * *}\end{array}$ & $\begin{array}{l}530^{* * *} \\
80\end{array}$ & $\begin{array}{l}30 \\
60\end{array}$ & $\begin{array}{l}110 \\
180\end{array}$ \\
\hline $\begin{array}{l}\text { Atrazine } \\
\text { X 2,4-D }\end{array}$ & $\begin{array}{l}5 \\
9\end{array}$ & $\begin{array}{l}3 \\
3\end{array}$ & $\begin{array}{l}3200 \\
2850\end{array}$ & $\begin{array}{r}50 \\
110\end{array}$ & $\begin{array}{l}40 \\
80\end{array}$ & $\begin{array}{r}20 \\
340\end{array}$ \\
\hline $\begin{array}{l}\text { Atrazine, } 1.12 \mathrm{~kg} \\
\times 2.24 \mathrm{~kg}\end{array}$ & $\begin{array}{l}6 \\
3\end{array}$ & $\begin{array}{l}2 \\
4\end{array}$ & $\begin{array}{l}3410 \\
2290\end{array}$ & $\begin{array}{l}60 \\
40\end{array}$ & $\begin{array}{l}40 \\
50\end{array}$ & $\begin{array}{l}30 \\
20\end{array}$ \\
\hline $\begin{array}{l}2,4-\mathrm{D}, 0.56 \mathrm{~kg} \\
\times 1.12 \mathrm{~kg}\end{array}$ & $\begin{array}{r}12 \\
5\end{array}$ & $\begin{array}{l}4 \\
3\end{array}$ & $\begin{array}{l}2640 \\
3060\end{array}$ & $\begin{array}{r}160 \\
50\end{array}$ & $\begin{array}{r}140 \\
30\end{array}$ & $\begin{array}{l}630^{* *} \\
40\end{array}$ \\
\hline \multicolumn{7}{|c|}{ Orthogonal interaction ( $1984 \times 1985$ retreatment) } \\
\hline $\begin{array}{l}\text { No herbicide } \\
\mathrm{X} \text { herbicide }\end{array}$ & ns & ns & ns & ns & ns & ns \\
\hline $\begin{array}{l}\text { Atrzine } \\
\times 2,4-D\end{array}$ & ns & ns & ns & ns & ns & ns \\
\hline $\begin{array}{l}\text { Atrazine, } 1.12 \mathrm{~kg} \\
\text { X } 2.24 \mathrm{~kg}\end{array}$ & ns & ns & ns & ns & ns & ns \\
\hline $\begin{array}{l}2,4-\mathrm{D}, 0.56 \mathrm{~kg} \\
\times 1.12 \mathrm{~kg}\end{array}$ & ns & ns & ns & * & ns & ns \\
\hline
\end{tabular}

$*, * * * * *$ Significant at the $0.10,0.05$, and 0.01 levels, respectively, $n s=$ no significant, interaction due to retreatment in 1985 .

$1 \mathrm{AMBPC}=$ western ragweed, $\mathrm{OF}=$ other forbs, $\mathrm{TOTG}=$ total grasses, $\mathrm{LS}=$ lespedeza sp. 
increase with the use of $0.56 \mathrm{~kg}$ ae/ ha of 2,4-D.

Retreatment in 1985 at Location III resulted in significant interactions for densities of heath aster and western ragweed comparisons (Table 5). Many of these interactions may be related to the lack of control of the undesirable forbs with the $1.12 \mathrm{~kg} / \mathrm{ha}$ rate of atrazine in 1984 (Table 2). Comparisons of the interactions with the 1.12 and the $2.24 \mathrm{~kg}$ rates of atrazine indicated significant interaction for density of western ragweed and other forbs, and standing crop of grasses and other forbs (data not shown). However, since there were no significant year interactions associated with standing crop of grass or forbs for the no herbicide versus herbicide orthogonal comparison, it is possible to compare herbicide effects at this location. There was a $75 \%$ reduction of lanceleaf ragweed and heath aster standing crop associated with herbicide treatments. This corresponded to a $78 \%$ increase in total grass standing crop due to herbicide treatment $(1,570 \mathrm{~kg} / \mathrm{ha})$. Comparisons of forb density after atrazine treatments indicated that there was a significant increase in control of forbs with the higher rate of atrazine. There were no significant differences in either forb density or standing crop of forbs or grass associated with the 2 rates of 2,4-D. This indicates that the $0.56 \mathrm{~kg} / \mathrm{ha}$ rate was sufficient for controlling the weed species present at this location.

\section{Conclusions}

Both 2,4-D and atrazine can be effectively used to control many of the undesirable forbs and increase grass standing crop on degraded grasslands of Oklahoma. Both density and standing crop of most of the major forbs in these studies were significantly reduced by both herbicides. The average increase in grass standing crop in 1984 attributed to herbicide applications was $71 \%(1,070$ $\mathrm{kg} / \mathrm{ha}$ ). Some differences in susceptibility of forbs to the herbicides and the activity of herbicides at different locations were observed. Heath aster occurred in $\mathbf{2}$ studies and was controlled better with 2,4-D than with atrazine. The decreased activity of the low rate of atrazine on forbs at Location III was attributed to tie-up of the herbicide by the silty clay loam soil. The reduced activity of the low rate of 2,4-D on western ragweed at Location II could not be explained by conditions at spraying, but increasing the rate of 2,4-D to $2.24 \mathrm{~kg} / \mathrm{ha}$ significantly reduced density and standing crop of western ragweed.

As a result of dense forb populations in the low rate of atrazine treated plots in 1985, significant reductions of common broomweed and western ragweed density resulted at Location $I$ and Location III, respectively, after retreatment with $1.12 \mathrm{~kg}$ of atrazine. Treatment with $0.56 \mathrm{~kg} /$ ha of 2,4-D in 1984 and 1985 at Location II resulted in significant increases in lespedeza standing crop and this increase was characterized with a shift from common lespedeza to sericea lespedeza.

Grass standing crop increased an average of about $61 \%(1,170$ $\mathrm{kg} / \mathrm{ha}$ ) in 1985 after a single herbicide treatment in 1984. Retreatment with herbicide in 1985 did not result in significant increase in grass production above the single application at any of the loca-

Table 5. Forb density and forb and grass standing crop for Location III in 1985.1

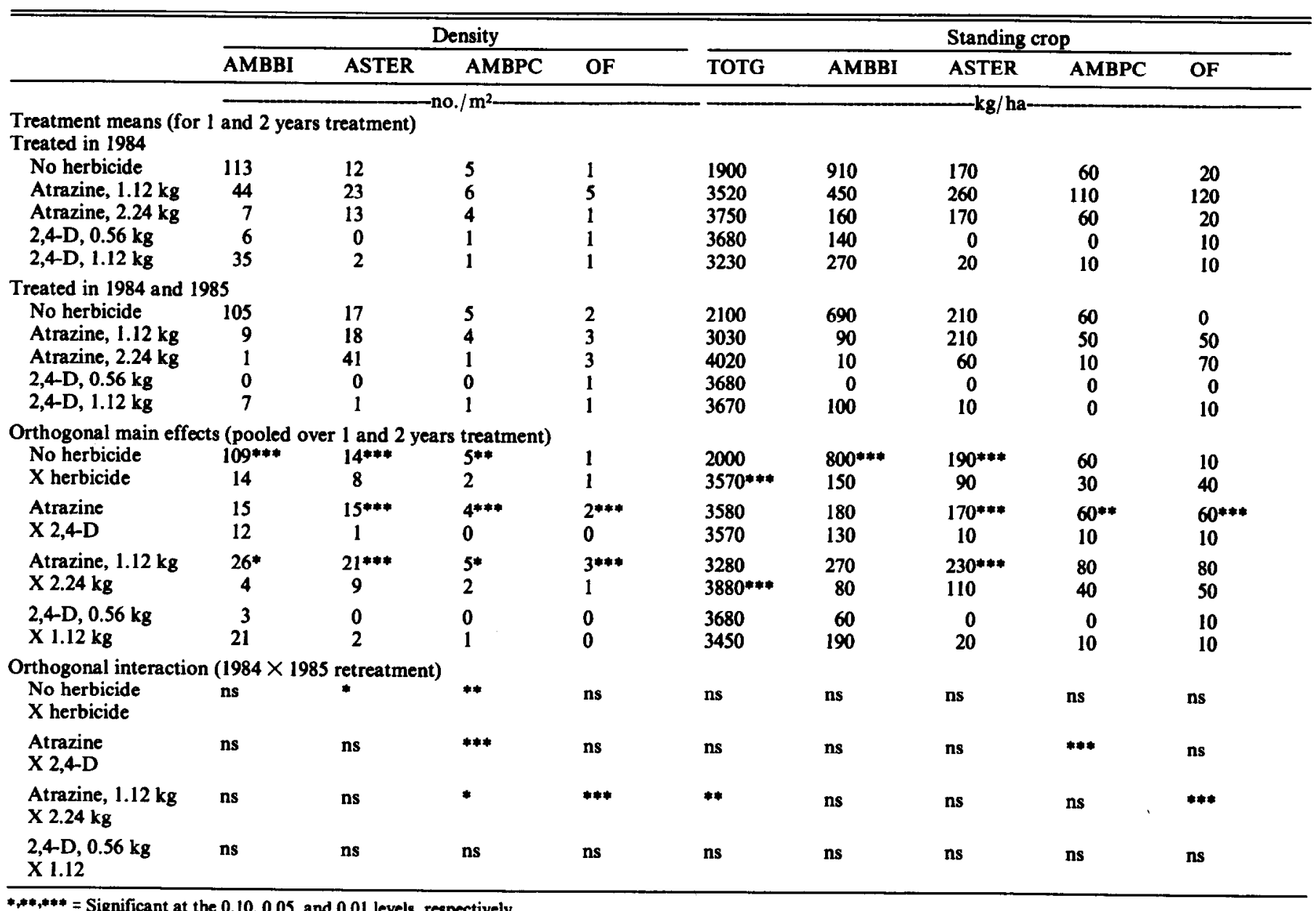

$* * * * *=$ Significant at the $0.10,0.05$, and 0.01 levels, respectively.

as = no significant, interaction due to retreatment in 1985 .

'AMBBI = lanceleaf ragweed, ASTER = heath aster, AMBPC = western ragweed, OF = other forbs, TOTG = total grasses. 
tions. This indicates that spraying herbicides for 2 successive years is not necessary.

\section{Literature Cited}

Ahmed, J., C.D. Bonham, and W.A. Laycock. 1983. Comparison of techniques used for adjusting biomass estimates by double sampling. J. Range Manage. 36:217-221.

Baker, R.L., J. Powell, R.D. Morrison, and J.F. Stritzke. 1980. Effects of atrazine, 2,4-D and fertilizer on crude protein content of Oklahoma tallgrass prairie. J. Range Manage. 33:404-407.

Dwyer, D.D. 1958. Competition between forbs and grasses. J. Range Manage. 11:115-118.

Houston, W.R. 1977. Species susceptibility to atrazine herbicide on shortgrass range. J. Range Manage. 30:50-52.

Hyder, D.N. 1971. Species susceptibilities to 2,4-D on mixed grass prairie. Weed Sci. 19:526-528.

Kay, B.L. 1971. Atrazine and simazine increase yield and quality of range forage. Weed Sci. 19:370-372.
McGinnles, W.J. 1984. Chemically thinning blue grama range for increased forage and seed production. J. Range Manage. 37:412-414.

Pechanec, J.F., and G.D. Pickford. 1937. A weight measurement method for the determination of range or pasture production. J. Amer. Soc. Agron. 29:894-904.

Petersen, J.L., R.L. Potter, and D.N. Ueckert. 1983. Evaluation of selected herbicides for manipulating herbaceous rangeland vegetation. Weed Sci. 31:735-739.

Powell, J., J.F. Stritzke, R.W. Hammond, and R.D. Morrison. 1982. Weather, soil and 2,4-D effects on tallgrass prairie in Oklahoma. J. Range Manage. 35:483-488.

Sims, P.L., and D.D. Dwyer. 1965. Pattern of retrogresion of native vegetation in north central Oklahoma. J. Range Manage. 18:20-25.

Waller, S.S., and D.K. Schmidt. 1983. Improvement of eastern Nebraska tallgrass range using at razine or glyphosate. J. Range Manage. 36:87-90. 